International Journal of Instruction

e-ISSN: 1308-1470 • www.e-iji.net

Article submission code

20200520042504

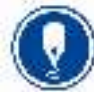

Received: 20/05/2020

Revision: 02/01/202
July $2021 \bullet$ Vol.14, No.3

p-ISSN: 1694-609X

pp. 547-566

Accepted: 27/01/2021

OnlineFirst: 03/06/2021

\title{
E-Learning in COVID-19 Pandemic: Does It Challenge Teachers' Work Cognition and Metacognitive Awareness?
}

\section{Iin Hindun}

Assoc. Prof., Universitas Muhammadiyah Malang, Indonesia, iinhindun@umm.ac.id

\section{H. Husamah}

Universitas Muhammadiyah Malang, Indonesia, usya_bio@umm.ac.id

N. Nurwidodo

Universitas Muhammadiyah Malang, Indonesia,nurwidodo@umm.ac.id

Diani Fatmawati

Universitas Muhammadiyah Malang, Indonesia,dianifatmawati87@umm.ac.id

\section{Ahmad Fauzi}

Universitas Muhammadiyah Malang, Indonesia,ahmad_fauzi@umm.ac.id

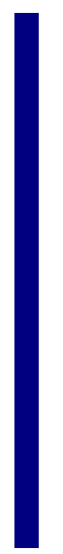

Teachers' competences are challenged in pandemic condition as they have to conduct the learning processes outside of their comfort zone. Work cognition (WC) and metacognitive awareness (MA) are acknowledged as the determinant indicators for teachers' professionalism. This study aimed at profile mapping the WC and MA in Malang during COVID-19 pandemic situation. The effect of demographic profile and the correlation of teachers' MA and WC were analyzed in this survey research. Percentage, two-way analysis of variance, and multiple linier regression were used in analyzing the data gained. The results showed that the majority teachers owned "good" MA and WC in which the factors of school level and teachers' certification status insignificantly affected the both aspects. On the other hand, civil servant status has significantly affected teachers' WC. Finally, teachers' teaching period and MA were significantly correlated to their WC. Hence, MA trainings are recommended to be conducted continuously to optimize teachers' WC.

Keywords: COVID-19 pandemic, e-learning, metacognitive awareness, teacher, work cognition

\section{INTRODUCTION}

World Health Organization (WHO) has designated Coronavirus Disease 2019 (COVID19) as the global pandemic (Mahase, 2020; Watkins, 2020). This pandemic, which is caused by Severe Acute Respiratory Syndrome Coronavirus 2 or SARS-CoV-2 (Li et

Citation: Hindun, I., Husamah, H., Nurwidodo, N., Fatmawati, D., \& Fauzi, A. (2021). E-Learning in COVID-19 pandemic: Does it challenge teachers' work cognition and metacognitive awareness? International Journal of Instruction, 14(3), 547-566. https://doi.org/10.29333/iji.2021.14332a 
al., 2020; Su et al., 2020) has infected millions people in more than two hundred countries around the world. The death rate caused by this disease has significantly reached hundred thousand people (Khan et al., 2020; Lin et al., 2020).

As the consequences, COVID-19 pandemic has been affecting several fields such as economic (Asian Development Bank, 2020; Jackson et al., 2020), social (Wenham et al., 2020), and psychology (Carvalho et al., 2020). Countries around the world have been experiencing economic pressure and population issues in terms of increasing unemployment as the consequences of work, production, and goods distribution terminations, the collapse of tourism sector as worst as the decrease or the loss of livelihood. On one hand, the countries must implement frugality, yet, on the other hand, they need great financial amount against COVID-19 (Bozorgmehr et al., 2020; Hsieh, 2020).

The COVID-19 development trend has given serious implication for public institutions (Ahmed et al., 2020), as considerable as affected the world education system (Anderson, 2020; Horn, 2020; van Fleet, 2020). There are many countries conduct temporary close of their education institutions to prevent COID-19 transmissions. Until April 2020, more than 421 million students have been given day off and learning at home. More than 180 countries implement national close, which affects to around $97 \%$ students around the world. In addition, some countries have also been conducting local close which affects millions students (Domenico et al., 2020; UNESCO, 2020b). Education institutions close their physical schools or campuses and move the coursework delivery online (Gee, 2020).

Not only does the schools close affect the school management, but it also influences students, teachers, and family. The most considerable consequence is the learning system, particularly of which related to digital and online learnings (Aderholt, 2020; Karp \& McGowan, 2020; UNESCO, 2020a). Almost of all schools choose online learning or e-learning option (Horn, 2020; Karp \& McGowan, 2020; van Fleet, 2020; Zhang et al., 2020), not excluding of Indonesia. The Ministry of Education and Culture of Indonesia has been applying online learning in all schools in Indonesia (Irawan, 2020; Kemendikbud, 2020; Wahyudi, 2020).

The learning system and condition changes are not separated to teacher's role (Thien et al., 2014; Zacharo et al., 2018), particularly the shifting learning pattern to online/elearning system. In online learning system, teachers are demanded to give their active contribution and commitment (San-Martín et al., 2020), readiness (Mirķe et al., 2019), literacy (Purnomo \& Jailani, 2019), and strong willing (Tao et al., 2019). Those are the factors covered in what Joo et al. (2017) so called with Work Cognition (WC). Moreover, (Joo et al., 2017) there are eight factors belong to work cognition i.e. meaningful work, autonomy, feedback, connectedness with colleagues, connectedness with leader, collaboration, distributive fairness, and growth. Teachers' commitment in working will support the optimum achievement and improvement of learning quality. Teachers play an important role in educating future society through their work in schools (Razak et al., 2009), even though there was no evidence supports the significant effect of teachers' commitment towards students' achievement (Park, 2005). The 
committed teachers are those who care of their profession in the context of supporting their students and hardly struggle to ensure that their students are learning something (Mart, 2013; Shernoff et al., 2011; Zeichner, 2008).

Two important factors which must be possessed by teachers in running their profession is "cognition" (Borg, 2005; Lee, 2018; Tanas et al., 2020) and metacognitive awareness (MA) (Duman \& Semerci, 2019; Karamustafaoğlu et al., 2018; Kuvac \& Koc, 2018). Cognition is a thinking property in which one of key element of many cognition definitions is the ability in self-visualizing in the wider world contexts (Breed \& Moore, 2016). One of cognition study is Work Cognition (WC). This study refers to person's cognition (employee/worker) about the workplace characteristics, either the work or its organization aspect, formed based on the cognitive assessments made from the workplace (Kim et al., 2015; Nimon \& Zigarmi, 2015; Nimon et al., 2011). Someone's WC, involves thinking scheme, comprised of several components i.e. feature, aspect, feeling, and idea related to the previous working experiences which are utilized to handle the recent job (Joo et al., 2017).

Meanwhile, MA is different with cognition. It is a part of thinking ability (Pantiwati \& Husamah, 2017), and characterized by high-level cognition (Duman \& Semerci, 2019). MA fulfills a unique niche within self-regulated phylum, by giving general-domain knowledge and regulatory skills which enable individuals to control their cognition in many domains. MA is flexible and strongly needed (Schraw, 1998), to recognize and regulate self-thinking in a real time way (Hughes, 2017; Schraw \& Dennison, 1994). In learning context, MA is an important element in comprehending teaching characteristics and developing teaching ability (Dori et al., 2018; Farahian, 2018). Teachers who have high MA will develop thinking habit which motivates themselves to often evaluate their performance and modify their point of view and attitude in accordance with the needs. The increase in MA enhances teachers to think reflectively about the teaching pattern of practices (Adadan \& Oner, 2018).

In the limited way, several studies about work cognition theme have been conducted by experts (Joo et al., 2017; Kim et al., 2015; Nimon \& Zigarmi, 2015; Nimon et al., 2011). Meanwhile, there also some experts conducted the studies which focused on MA and online learning such as digital card game and MA (Braad et al., 2019), web-based self-monitoring protocols and MA (Schmidt et al., 2012), online versus face-to-face instruction on MA (Rapchak, 2018), Moodle as virtual learning environment and MA (Gulbinskienè et al., 2017), foreign language learning through Facebook and MA (Peeters, 2015), and flipped learning (Y. Zhang et al., 2019). Those all studies used students as the subject and none of which focused on teachers. Yet the studies about teachers in its relation with MA have been done by researchers (Bulut, 2018; Hughes, 2017; Kallio et al., 2017; Karamustafaoğlu et al., 2018; Memnun \& Akkaya, 2009), and the others focused on teacher candidates (Adadan \& Oner, 2018; Adadan, 2020; Batdal Karaduman \& Erbaş, 2017; Duman \& Semerci, 2019; Karataş, 2017; Kuvac \& Koc, 2018). However, there has no study addressed MA and teachers in e-learning system. Furthermore, none of the studies concerned about teacher's WC, especially in e- 
learning. In the other words, MA and WC studies in e-learning, particularly in outbreak situation is scarce.

The contribution of this study will be the novel information in MA, WC, and online learning studies in their correlation with the improvement of teacher's professionalism. The subjects in this study were teachers in Indonesia, thus, for the finding's generalization to the wider population, the further studies in the other pandemic-affected countries are crucial to be done by the other researchers. Yet, as it is online learning, the measuring instruments used and pandemic condition in this study are universal, thus, the findings in this research are likely to be valid for the other various populations. Hence, this study aimed at investigating teachers' WC and MA profiles as well as the correlation between these two elements during teaching using e-learning in COVID-19 pandemic situation.

\section{METHOD}

\section{Study Design}

This survey research was designed to explore teachers' WC and MA profiles as well as the correlation between the two elements during COVID-19 pandemic. This research was conducted in Indonesia by involving teachers in Malang. The data collection was done between March and April 2020. This time was the period in which COVID-19 outbreak has entered Indonesia based on the official statement of Indonesian Republic President. The Ministry of Education and Culture of Indonesia has instructed schools to hold online learning by utilizing various platforms in which the use can be freely chosen by teachers.

\section{Study Site and Respondent Selection}

The research location was chosen in Malang (comprised of three districts), East Java, Indonesia. Malang is one of education city in Indonesia which was designated as the red zone for COVID-19 spread. The respondents of this research were teachers in Malang area. The school levels involved in this research were those from elementary to senior high school. There was no respondent criteria determined by researchers, hence, the population of this study was teachers in red zone area.

\section{Data Collection Instrument and Procedures}

The data collection was done using questionnaires designed by previous researchers. The Awareness Inventory for Teachers (Balcikanli, 2011) was used to measure teachers' MA. This instrument composed of six factors, i.e. Factor I- Declarative Knowledge (statement 1, 7, 13, 19), Factor II- Procedural Knowledge (statement 2, 8, 14, 20), Factor III- Conditional Knowledge (statement 3, 9, 15, 21), Factor IV- Planning (statement 4, 10, 16, 22), Factor V- Monitoring (statement 5, 11, 17, 23), and Factor VI Evaluating (statement 6,12,18,24). Meanwhile, the Work Cognition Inventory-Revised (Nimon \& Zigarmi, 2015) was used to measure teachers' WC. It comprised of 12 aspects, namely, autonomy, collaboration, and connectedness with colleagues, connectedness with leader, distributive justice, procedural justice, feedback, growth, meaningful work, workload balance, task variety, and performance expectations. 
The both instruments required the respondents to state their agreement toward the all items asked. Likert scale was used to collect the agreement of each respondent in each item. This scale comprised of five scales from strongly disagree to strongly agree. In accordance with Malang conditions when this research has been conducted, the questionnaire was transformed into online questionnaire by using Google Form platform. Furthermore, the questionnaire link was spread to the all teachers in Malang as the respondents of this research. They were asked to fill the demographic profile which included the school levels they were teaching at, the certification, the status, and their teaching period.

\section{Data Analysis}

The survey data has been downloaded in .csv format which then was checked by researchers before the analysis was done. The analysis was aided using Microsoft Excel and SPSS. The teachers' demographic data were calculated using percentage and presented in table from. The responses of each teacher in each MAIT item and WCI-R were converted into score 1 to 5 , where score 1 was given to the strongly disagree response and score 5 was given to the strongly agree response. After the responses were scored, the teachers' MA and WC were grouped into "good", "moderate", or "low" based on Bloom cut-off point. As the teacher's score reached $80 \%$ of the optimal score, the respondent was categorized as "good"; meanwhile, those who reached 60 to $79 \%$ of the optimal score were categorized in "moderate"; and the "low" category was given to them who the score below $60 \%$. The grouping results were then served in doughnut graph.

The data gained was tested its normality using Kolmogorov-Smirnov. Meanwhile data homogeneity was ensured using Levene's test. As the assumption tests were fulfilled, Three-way analysis of variance (ANOVA) was done to analyze the effect of school level, teacher's certification, and teacher's status toward their MA and WC. For the factor proven to pay significant effect, the test was continued using Least Significant Difference (LSD) with the significance level of 5\%. After the ANOVA test was performed, the multiple regression analysis was run to analyze whether there was a significant correlation between teachers' teaching period and MA variables and their WC.

\section{FINDINGS AND DISCUSSION}

\section{Respondents}

The data collected through the questionnaire were recapitulated. As the results, there were 131 teachers fulfilled the questionnaire. The demographic profile of teachers was served in Table 1. The respondents comprised of 32 Elementary School (ES) teachers, 70 Junior High School (JHS) teachers, and 29 Senior High School (SHS) teachers. Based on Table 1 it can be seen that $71.8 \%$ teachers were certified and $56.5 \%$ teachers' status were Civil Servant (CS) in which the remain (43.5\%) were Non-Civil Servant (NCS). Moreover, the majority teachers have been teaching for more than 20 years. 
Table 1

The demographic profile of teachers who were the research respondents

\begin{tabular}{|c|c|c|c|c|}
\hline \multirow{2}{*}{ Variable } & \multicolumn{3}{|c|}{ School level of teachers' teaching place } & \multirow[t]{2}{*}{ Total n (\%) } \\
\hline & $\mathrm{ES} n(\%)$ & JHS n $(\%)$ & SHS n $(\%)$ & \\
\hline \multicolumn{5}{|l|}{ Certification } \\
\hline Uncertified & $8(25.0 \%)$ & $19(27.1 \%)$ & $10(34.5 \%)$ & $37(28.2 \%)$ \\
\hline Certified & $24(75.0 \%)$ & $51(72.9 \%)$ & $19(65.5 \%)$ & $94(71.8 \%)$ \\
\hline \multicolumn{5}{|l|}{ Status } \\
\hline NCS & $9(28.1 \%)$ & $27(38.6 \%)$ & $21(72.4 \%)$ & $57(43.5 \%)$ \\
\hline $\mathrm{CS}$ & $23(71.9 \%)$ & $43(61.4 \%)$ & $8(27.6 \%)$ & $74(56.5 \%)$ \\
\hline \multicolumn{5}{|c|}{ Teaching period } \\
\hline $1-5$ years & $1(3.1 \%)$ & $1(3.1 \%)$ & $6(20.7 \%)$ & $20(15.3 \%)$ \\
\hline $6-10$ years & $7(21.9 \%)$ & $7(21.9 \%)$ & $9(31.0 \%)$ & $26(19.8 \%)$ \\
\hline $11-15$ years & $3(9.4 \%)$ & $3(9.4 \%)$ & $8(27.6 \%)$ & $20(15.3 \%)$ \\
\hline $16-20$ years & $6(18.8 \%)$ & $6(18.8 \%)$ & $0(0.0 \%)$ & $17(13.0 \%)$ \\
\hline$>20$ years & $15(46.9 \%)$ & $15(46.9 \%)$ & $6(20.7 \%)$ & $48(36.6 \%)$ \\
\hline
\end{tabular}

\section{Teachers' MA and WC profile}

Figure 1 depicts the level of teachers' MA and WC. Based on Fig. 1, the majority teachers possessed good MA level. On the other hand, only $2 \%$ teachers were categorized in low level. This in line with the $\mathrm{WC}$ level in which the majority teachers have good WC. However, the percentage of teachers with good WC (58\%) were lower compared to those who possessed good MA $(80 \%)$. Contrarily, there only $3 \%$ teachers who were categorized in low level.
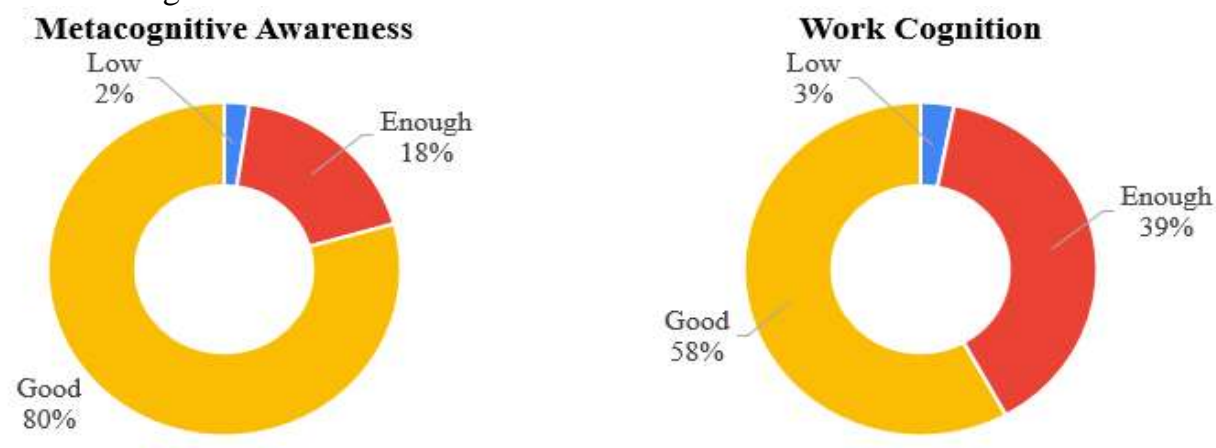

Figure 1

The MA and WC profiles of teachers in Malang Raya

Effect of school level, certification, and teachers' status toward teachers' MA and WC

Table 2 informs the mean scores comparation of MA and WC based on school level, certification, and teachers' status. The normality test was conducted on the residual data 
and variance homogenity between groups. The Kolmogorov-Smirnov test results showed that the both MA $[\mathrm{D}(131)=0,073, \mathrm{p}=0,087]$ and $\mathrm{WC}[\mathrm{D}(131)=0,045, \mathrm{p}=$ $0,200]$ residual data were normally distributed. Moreover, Levene's test depicted that the homogenity assumption was fulfilled either the MA $[\mathrm{F}(10,120)=0,762, \mathrm{p}=0,64]$ or $\mathrm{WC}[\mathrm{F}(10,120)=1,282, \mathrm{p}=0,248]$.

Table 2

The means comparison of teachers' MA and WC based on school level, certification, and teachers' status aspects.

\begin{tabular}{|c|c|c|c|c|}
\hline School & Status & Certification & MA & WC \\
\hline \multirow{9}{*}{$\begin{array}{l}\text { Elementary } \\
\text { School }\end{array}$} & \multirow{3}{*}{ Non-Civil Servant } & Uncertified & 106.67 & 128.50 \\
\hline & & Certified & 105.67 & 148.00 \\
\hline & & Total & 106.33 & 135.000 \\
\hline & \multirow{3}{*}{ Civil Servant } & Uncertified & 112.00 & 149.00 \\
\hline & & Certified & 103.38 & 151.95 \\
\hline & & Total & 104.13 & 151.70 \\
\hline & \multirow{3}{*}{ Total } & Uncertified & 108.00 & 133,63 \\
\hline & & Certified & 103.67 & 151.46 \\
\hline & & Total & 104.75 & 147.00 \\
\hline \multirow{9}{*}{ JHS } & \multirow{3}{*}{ Non-Civil Servant } & Uncertified & 98.53 & 133.53 \\
\hline & & Certified & 105.25 & 151.83 \\
\hline & & Total & 101.52 & 141.67 \\
\hline & \multirow{3}{*}{ Civil Servant } & Uncertified & 105.25 & 144.00 \\
\hline & & Certified & 102.18 & 147.28 \\
\hline & & Total & 102.47 & 146.98 \\
\hline & \multirow{3}{*}{ Total } & Uncertified & 99.95 & 135.74 \\
\hline & & Certified & 102.90 & 148.35 \\
\hline & & Total & 102.10 & 144.93 \\
\hline \multirow{8}{*}{ SHS } & \multirow{3}{*}{ Non-Civil Servant } & Uncertified & 99.10 & 132.10 \\
\hline & & Certified & 98.91 & 138.82 \\
\hline & & Total & 99.00 & 135.62 \\
\hline & \multirow{2}{*}{ Civil Servant } & Certified & 107.75 & 158.63 \\
\hline & & Total & 107.75 & 158.63 \\
\hline & \multirow{3}{*}{ Total } & Uncertified & 99.10 & 132.10 \\
\hline & & Certified & 102.63 & 147.16 \\
\hline & & Total & 101.41 & 141.97 \\
\hline \multirow{9}{*}{ Total } & \multirow{3}{*}{ Non-Civil Servant } & Uncertified & 100.29 & 132.10 \\
\hline & & Certified & 102.62 & 145.89 \\
\hline & & Total & 101.35 & 138.39 \\
\hline & \multirow{3}{*}{ Civil Servant } & Uncertified & 107.50 & 145.67 \\
\hline & & Certified & 103.21 & 150.06 \\
\hline & & Total & 103.55 & 149.70 \\
\hline & \multirow{3}{*}{ Total } & Uncertified & 101.46 & 134.30 \\
\hline & & Certified & 103.04 & 148.90 \\
\hline & & Total & 102,60 & 144.78 \\
\hline
\end{tabular}

Table 3 and Table 4 are respect summarize the ANOVA test results of teachers' MA and WC. The analysis results show that almost of all the factors did not give significant effect on teachers' MA (P-value $>0.05$ ); yet, the factor significantly affect teachers' MA was their status $[\mathrm{F}(1,120)=5.529, \mathrm{P}=0.020, \eta \mathrm{p} 2=0.044]$. Table 2 informs that the 
mean value of civil servant teachers' $\mathrm{MC}(\mathrm{M}=149.70)$ was higher than non-civil servant teachers' $(M=138.39)$. Hence, civil servant teachers possess significantly higher WC scores compared to those non-civil servants. Furthermore, no significant interaction occurred either in teachers' MA or WC.

Table 3

The effect of school level, certification, and teachers' status toward teachers' MA

\begin{tabular}{lllllll}
\hline Source & $\begin{array}{l}\text { Type III Sum } \\
\text { of Squares }\end{array}$ & df & $\begin{array}{l}\text { Mean } \\
\text { Square }\end{array}$ & F & Sig. & $\begin{array}{l}\text { Partial } \\
\text { Squared }\end{array}$ \\
\hline Corrected Model & $1168.819^{\mathrm{a}}$ & 10 & 116.882 & 0.648 & 0.770 & 0.051 \\
\hline Intercept & 597776.879 & 1 & 597776.879 & 3316.570 & 0.000 & 0.965 \\
\hline School & 185.350 & 2 & 92.675 & 0.514 & 0.599 & 0.008 \\
\hline Certification & 52.634 & 1 & 52.634 & 0.292 & 0.590 & 0.002 \\
\hline Status & 240.172 & 1 & 240.172 & 1.333 & 0.251 & 0.011 \\
\hline School * Certification & 183.747 & 2 & 91.874 & 0.510 & 0.602 & 0.008 \\
\hline School * Status & 403.566 & 2 & 201.783 & 1.120 & 0.330 & 0.018 \\
\hline Certification * Status & 205.651 & 1 & 205.651 & 1.141 & 0.288 & 0.009 \\
\hline $\begin{array}{l}\text { School * Certification } \\
* \text { Status }\end{array}$ & 3.191 & 1 & 3.191 & 0.018 & 0.894 & 0.000 \\
\hline Error & 21628.738 & 120 & 180.239 & & & \\
\hline Total & 1401680.000 & 131 & & & & \\
\hline Corrected Total & 22797.557 & 130 & & & & \\
\hline a. R Squared = .051 (Adjusted R Squared = -.028)
\end{tabular}

Table 4

The effect of school level, certification, and teachers' status on teachers' WC level

\begin{tabular}{|c|c|c|c|c|c|c|}
\hline Source & $\begin{array}{l}\text { Type III Sum of } \\
\text { Squares }\end{array}$ & df & Mean Square & $\mathrm{F}$ & Sig. & $\begin{array}{l}\text { Partial Eta } \\
\text { Squared }\end{array}$ \\
\hline Corrected Model & $9010.419^{\mathrm{a}}$ & 10 & 901.042 & 2.580 & 0.007 & 0.177 \\
\hline Intercept & 1145607.359 & 1 & 1145607.359 & 3280.650 & 0.000 & 0.965 \\
\hline School & 62.912 & 2 & 31.456 & 0.090 & 0.914 & 0.001 \\
\hline Certification & 1061.629 & 1 & 1061.629 & 3.040 & 0.084 & 0.025 \\
\hline Status & 1930.818 & 1 & 1930.818 & 5.529 & 0.020 & 0.044 \\
\hline School * Certification & 439.116 & 2 & 219.558 & 0.629 & 0.535 & 0.010 \\
\hline School $*$ Status & 1694.072 & 2 & 847.036 & 2.426 & 0.093 & 0.039 \\
\hline Certification * Status & 676.313 & 1 & 676.313 & 1.937 & 0.167 & 0.016 \\
\hline $\begin{array}{l}\text { School * Certification * } \\
\text { Status }\end{array}$ & 1.588 & 1 & 1.588 & 0.005 & 0.946 & 0.000 \\
\hline Error & 41904.161 & 120 & 349.201 & & & \\
\hline Total & 2796786.000 & 131 & & & & \\
\hline Corrected Total & 50914.580 & 130 & & & & \\
\hline
\end{tabular}

a. R Squared $=.177$ (Adjusted R Squared $=.108$ )

\section{Correlation between teachers' teaching period and MA towards their WC}

Table 5 shows the regression analysis results. Column with $\mathrm{R}$ label in Table 5 shows the multiple correlation coefficient, while $\mathrm{R}$ square column contained of determination value. Based on Table 5, $\mathrm{R}$ value obtained was 0.669. This means that there was a strong correlation between teaching period and MA toward WC. In addition, the adjusted R2 was 0.439 . The information obtained from this value is that the teachers' 
teaching period and MA contributed $43.9 \%$ in explaining teachers' $\mathrm{WC}$ and the $56.1 \%$ remained was determined by the other variables excluded from this research's variables.

Table 5

Model summary of regression analysis

\begin{tabular}{lllll}
\hline Model & R & R Square & Adjusted R Square & Std. Error of the Estimate \\
\hline 1 & 0.669 & 0.448 & 0.439 & 14.81717 \\
\hline
\end{tabular}

Table 5 shows the analysis results of ANOVA to know whether the predictor has significant correlation with the criterion or not. Based on Table 5, it is obviously shown that the $\mathrm{F}$ value obtained was 51.953 with $\mathrm{P}$-value $<0.0001$. Thus, it can be concluded that teaching period and MA have significant correlation with teachers' WC. Eventually, based on Table 6 , the regression line equation obtained was $\mathrm{Y}=47,779+0,506 \mathrm{X} 1+$ $0,859 \mathrm{X} 2$, where $\mathrm{Y}$ is $\mathrm{WC}, \mathrm{X} 1$ is teaching period, and $\mathrm{X} 2$ is MA.

Table 6

The summary of one-way ANOVA test results of the correlation between teachers' teaching period and MA and teachers' WC

\begin{tabular}{lllllll}
\hline Model & Sources & Sum of Squares & df & Mean Square & F & Sig. \\
\hline 1 & Regression & 22812.367 & 2 & 11406.184 & 51.953 & $<0.0001$ \\
& Residual & 28102.213 & 128 & 219.549 & & \\
& Total & 50914.580 & 130 & & & \\
\hline
\end{tabular}

Table 7

The summary of regression coefficients calculation

\begin{tabular}{lllllll}
\hline \multirow{2}{*}{ Model } & \multicolumn{2}{l}{ Unstandardized Coefficients } & $\begin{array}{l}\text { Standardized } \\
\text { Coefficients }\end{array}$ & t & \multirow{2}{*}{ Sig. } \\
\hline & & $\mathrm{B}$ & Std. Error & Beta & & \\
\hline \multirow{2}{*}{1} & (Constant) & 47.799 & 10.181 & & 4.695 & $<0.001$ \\
\cline { 2 - 7 } & Teaching period & 0.506 & 0.122 & 0.275 & 4.148 & $<0.001$ \\
\cline { 2 - 8 } & MA & 0.859 & 0.099 & 0.575 & 8.680 & $<0.001$ \\
\hline
\end{tabular}

By referring to the equation formed, it can be seen that the higher the teachers' MA, the higher their WC will be. In the other words, as the teachers experienced teaching longer period of time, their WC going higher little by little. As the consequences, if the teachers are given the trainings which advance their MA, their WC will be faster improved as well.

MA is crucial in learning (Abdellah, 2015; Bulut, 2018) due to its effect towards students. Teachers who possessed higher metacognitive awareness produces students with good academic achievement (Duman \& Semerci, 2019; Palantis et al., 2018), as their independent learning abilities are well developed (Hughes, 2017; Okoza \& Aluede, 2014). The data showed that the majority teachers possessed good MA and WC. It is assumed that the undergirding reason of the fact is the long experiences owned by teachers, this is supported by the strong correlation between teachers' teaching period and MA toward their WC. Teachers' teaching period and teaching experiences influence 
their MA (C. B. Lee et al., 2010; Ozturk, 2018; Zohar, 1999) because the teachers have adequate time as well as experiences to share their own thinking process (Wilson \& Bai, 2010). The teacher's experience will relate to how many years he has worked in class (Burroughs et al., 2019). The high percentage of teachers with good MA level was also supported by the intervention of the e-learning utilization (Rapchak, 2018), because learning implementation in technology affects the development of individual ability to develop their metacognition ability (Maryati et al., 2020). Hence, in case there are some teachers' with low MA score, it is probably because of their inability in catching technology trend in education and learning (Gurbin, 2015; Turky, 2018).

The data which proved that the majority teachers owned good WC level is a positive point. The experiences possessed by someone are correlated with WC (Nimon \& Zigarmi, 2015; Nimon et al., 2011). A person's assessment of their work experience will involve a number of things, namely cognitive (or rational), affective (or emotional) assessment, and a simultaneous decision-making process (Joo et al., 2017). Being a teacher means committing continuous process along with development era. Not only does this profession related to routine behavior, but it is also related to attitude, and professional concept. One of important elements in the development of teachers' professionalism is that the knowledge possessed is converted to professional activities, and various advance knowledge obtained from that continuous processes (Bromme \& Brophy, 1986). Teachers' work satisfaction and the important contributed factors, along with the passage of time, can improve teachers' motivation and performances (Ramos et al., 2018). Moreover, teachers' self-efficacy and involvement are reciprocally developed from time to time as well as teachers' involvement and satisfaction are intercorrelated with the time overs (Granziera \& Perera, 2019). Teachers' cognitive processes are influenced by technology (Beach \& Willows, 2017) in which one of them is the application of online teaching (Darbyshire, 2004; Gregory \& Bannister-Tyrrell, 2017).

This research results are in line with the previous studies. There was positive significant correlation between metacognitive and cognitive awareness on adults people (Jain \& Kumar, 2013). This awareness encourages someone to do the continuous improvement by increasing their work quality (Welch et al., 2018). The reflective activity done by teachers is a part of metacognitive awareness performance which is strategic for their work. Without any reflection, some people will face obstacles and frustration in assessing their own work (Jaleel \& Premachandran, 2016). Besides that, someone will identify his/her main goals and willing to optimize his/her hard work and perseverance to achieve the goals. The continuous practices in this matter will, in turn, improve teachers' metacognition awareness and influence their academic work performance (Ingole \& Pandya, 2016).

The interesting finding in this research was albeit that the ANOVA test results (see Table 3) showed the significant effect of teachers' status towards WC (civil servant teachers owned higher WC compared to non-civil servant teachers), yet non civil servant teachers could also possess better WC level compared to those who were civil servant in case the schools they were working at can provide trainings which enable the teachers to improve their MA which lead to the encouragement of teachers' WC level. According to 
(Demirel et al., 2015), the way someone works is related to MA. It, somehow, determines the real teaching attitudes and teaching results (Wen, 2012). Meanwhile, (Marjon \& Nugroho, 2019) argued that teachers' status, either civil servant or non-civil servant tend to have no effect on teachers' work quality and competencies. Conversely, the principal leadership and teachers' personality are the determinant factors for those two aspects. The ability in issuing the policies in assigning teachers to attend various trainings which give positive impact to teachers' competencies is important (Halamish, 2018; Muazza et al., 2019). Various trainings will affect MA level (Perry et al., 2019) besides give positive impact for schools as teacher is an MA role model for students (Wall \& Hall, 2016). The other important factors decide teachers' MA are teachers' educational background and the place they completed their teaching education. Rokhman, Ahmadi, and Kusumaningtyas (2017) reported that teachers' performance is not only about their salary or promotion, but it, basically, about teacher colleges' development as the institutions produce teachers.

In ideal conditions, the certified teachers should be grouped as professional teachers (Uriegas et al., 2014) and showed to be the professionals who have flexibility and adaptation ability in the changing contexts and new work situations (Manasia et al., 2020). Certification is a formal prove and recognition given for teachers as the professionals (Lailatussaadah, 2015). However, the findings of this research showed that certification did not pay significant effect towards teachers' WC. This also in line with Darling-Hammond (Darling-Hammond et al., 2005) who stated that teachers' experiences and competences are the more dominant factors determine their professionalism compared to their certification. In fact, teachers are strongly depended to their certification, so that, if the certification funding support is eliminated, the teachers' performance will be decreased as well (Fuad, 2017). Similarly, (Kusumawardhani, 2017; Mukhtar et al., 2019) agreed that no strong evidence proves that the certification contributes positive effect towards teachers' effective performances. The increase in teacher income is not based on superior performance. One of the reasons is the absence of obligation to show teachers' improvement in work performance. Therefore, certification has been seen as merely the giving additional incentive without any requirement. Yet, according to (Kube et al., 2012), certification shows weak support in someone's productivity performance.

Based on the findings, certification program needs to be evaluated. In early level, according to (Tambingon, 2018), the school principal must be ready and capable in mobilizing teachers, mainly those who are certified, to achieve the goals determined and be more responsible in school education system. The same recommendations were also stated by (Kartini \& Kristiawan, 2019; Musthafa et al., 2017). They claimed that teachers in Indonesia should realize that certification is not the highest achievement for teachers. They should improve their performance, commitment, and show work attitude which focused on conducting their tasks and their responsibilities. Not only are teachers expected to possess high metacognitive level, but they are also expected to empower students' metacognitive. The premise undergirding this suggestion is the unoptimized Indonesian students' metacognitive (Fauzi \& Sa'diyah, 2019), yet metacognitive is a crucial component in supporting students' academic succeed in 21 st century. 


\section{CONCLUSION}

The exploration of teachers' MA and WC during COVID-19 outbreak was analyzed in this research which involved 131 teachers from elementary to senior high school levels. This can be concluded that most of the teachers owned good level of MA and WC. In addition, school level, certification status, as well as civil servant status give no significant effect to teachers' MA. Moreover, school level and certification status have also no significant impact toward teachers' WC. However, civil servant status significantly affects teachers' WC. Finally, teachers' teaching period, cumulatively, have significant correlation with their WC.

The interesting finding of this research is that the certification status did not give significant effect toward either teachers' WC or MA. Yet, certification status represents teachers' professionalism. These findings are expected to be able to provide considerations for the evaluation of teachers' certification program in Indonesia. Furthermore, based on regression analysis, it can be concluded that the longer the teaching period, the better the teachers' WC. However, MA also gives positive effect toward the improvement of teachers' WC. Thus, MA trainings are recommended to be conducted continuously to optimize the development of teachers' WC.

\section{ACKNOWLEDGMENT}

The author would like to thank Rector, Vice Rector for Academic and Islamic Development, and Director of Research and Community Service Directorate of Universitas Muhammadiyah Malang for the moral and material support in this research.

\section{REFERENCES}

Abdellah, R. (2015). Metacognitive awareness and its relation to academic achievement and teaching performance of pre-service female teachers in Ajman University in UAE. Procedia - Social and Behavioral Sciences, 174, 560-567. https://doi.org/10.1016/j.sbspro.2015.01.707

Adadan, E. (2020). Analyzing the role of metacognitive awareness in preservice chemistry teachers' understanding of gas behavior in a multirepresentational instruction setting. Journal of Research in Science Teaching, 57(2), 253-278. https://doi.org/10.1002/tea.21589

Adadan, E., \& Oner, D. (2018). Examining preservice teachers' reflective thinking skills in the context of web-based portfolios: The role of metacognitive awareness. Australian Journal Teacher Education, 43(11), 26-50. https://doi.org/10.14221/ajte.2018v43n11.2

Aderholt, R. (2020, March). Coronavirus outbreak shining an even brighter light on internet disparities in rural America. The Hill.

Ahmed, H., Allaf, M., \& Elghazaly, H. (2020). COVID-19 and medical education. The Lancet Infectious Diseases, 2019(20), 30226. https://doi.org/10.1016/S14733099(20)30226-7

Anderson, J. (2020, March). Should schools close when coronavirus cases are still rare? Quartz. 
Asian Development Bank. (2020). The economic impact of the COVID-19 outbreak on developing Asia (No. 128; ADB Briefs, Vol. 9, Issue 128). https://doi.org/10.22617/BRF200096

Balcikanli, C. (2011). Metacognitive awareness inventory for teachers (MAIT). Electronic Journal of Research in Educational Psychology, 9(3), 1309-1332. https://doi.org/10.25115/ejrep.v9i25.1620

Batdal Karaduman, G., \& Erbaş, A. A. (2017). Investigation of primary school teacher candidates' metacognitive awareness level. Journal for the Education of Gifted Young Scientists, 5(4), 31-48. https://doi.org/10.17478/JEGYS.2017.68

Beach, P., \& Willows, D. (2017). Understanding teachers' cognitive processes during online professional learning: A methodological comparison. Online Learning Journal, 21(1), 60-84. https://doi.org/10.24059/olj.v21i1.949

Borg, S. (2005). Teacher cognition in language teaching. Expertise in Second Language Learning and Teaching, 190-209. https://doi.org/10.1057/9780230523470_10

Bozorgmehr, K., Saint, V., Kaasch, A., Stuckler, D., \& Kentikelenis, A. (2020). Comment COVID and the convergence of three crises in Europe. The Lancet Public Health, 2(20), 10-11. https://doi.org/10.1016/S2468-2667(20)30078-5

Braad, E., Degens, N., \& Ijsselsteijn, W. (2019). Meco: A digital card game to enhance metacognitive awareness. In L. Elbaek, G. Majgaard, A. Valente, \& S. Khalid (Eds.), Proceedings of the European Conference on Games-based Learning (pp. 92-100). Dechema e.V. https://doi.org/10.34190/GBL.19.066

Breed, M. D., \& Moore, J. (2016). Cognition. In Animal behavior (2nd Editio, pp. 175209). Academic Press. https://doi.org/10.1016/B978-0-12-801532-2.00006-4

Bromme, R., \& Brophy, J. (1986). Teachers' cognitive activities. In B. Christiansen, A. G. Howson, \& M. Otte (Eds.), Perspectives on mathematics education (2nd Ed.). Springer. https://doi.org/10.1007/978-94-009-4504-3_3

Bulut, İ. (2018). The levels of classroom and pre-school teachers' metacognitive awareness. Universal Journal of Educational Research, 6(12), 2697-2706. https://doi.org/10.13189/ujer.2018.061201

Burroughs, N., Gardner, J., Lee, Y., Guo, S., Touitou, I., Schmidt, K., \& William, J. (2019). A review of the literature on teacher effectiveness and student outcomes. In Teaching for exelence and equity (6th ed., Issue 2007, pp. 7-17). Springer, Cham. https://doi.org/10.1007/978-3-030-16151-4

Carvalho, P. M. de M., Moreira, M. M., de Oliveira, M. N. A., Landim, J. M. M., \& Neto, M. L. R. (2020). The psychiatric impact of the novel coronavirus outbreak. Psychiatry Research, 286, 1-6. https://doi.org/10.1016/j.psychres.2020.112902

Darbyshire, P. (2004). Instructional technologies: Cognitive aspects of online programs. IRM Press. https://doi.org/10.4018/978-1-59140-565-8

Darling-Hammond, L., Holtzman, D. J., Gatlin, S. J., \& Heilig, J. V. (2005). Does teacher preparation matter? Evidence about teacher certification, teach for America, and 
teacher effectiveness. Education Policy Analysis Archives, 13(42), 1-51. https://doi.org/10.14507/epaa.v13n42.2005

Demirel, M., Aşkın, İ., \& Yağcı, E. (2015). An investigation of teacher candidates' metacognitive skills. Procedia - Social and Behavioral Sciences, 174, 1521-1528. https://doi.org/10.1016/j.sbspro.2015.01.783

Domenico, L. Di, Pullano, G., Coletti, P., Hens, N., \& Colizza, V. (2020). Expected impact of school closure and telework to mitigate COVID-19 epidemic in France.

Dori, Y. J., Avargil, S., Kohen, Z., Saar, L., \& Dori, Y. J. (2018). Context-based learning and metacognitive prompts for enhancing scientific text comprehension. International Journal of Science Education, O(0), 1-23. https://doi.org/10.1080/09500693.2018.1470351

Duman, B., \& Semerci, Ç. (2019). The effect of a metacognition-based instructional practice on the metacognitive awareness of the prospective teachers. Universal Journal of Educational Research, 7(3), 720-728. https://doi.org/10.13189/ujer.2019.070311

Farahian, M. (2018). Metacognitive awareness of skilled and less-skilled EFL writers.

Fauzi, A., \& Sa'diyah, W. (2019). Students' metacognitive skills from the viewpoint of answering biological questions: Is it already good?. Jurnal Pendidikan IPA Indonesia, 8(3), 317-327. https://doi.org/10.15294/jpii.v8i3.19457

Fuad, N. (2017). Pengaruh sertifikasi guru terhadap peningkatan kinerja guru PAI DI SMP dan MTs. Jurnal Manajemen Pendidikan, 8(1), 23-32. https://doi.org/10.21009/jmp.08103

Gee, G. (2020). COVID-19: Impact on student predictions.

Granziera, H., \& Perera, H. N. (2019). Relations among teachers' self-efficacy beliefs, engagement, and work satisfaction: A social cognitive view. Contemporary Educational Psychology, 58(February), 75-84. https://doi.org/10.1016/j.cedpsych.2019.02.003

Gregory, S., \& Bannister-Tyrrell, M. (2017). Digital learner presence and online teaching tools: higher cognitive requirements of online learners for effective learning. Research and Practice in Technology Enhanced Learning, 12(18), 1-17. https://doi.org/10.1186/s41039-017-0059-3

Gulbinskienè, D., Masoodi, M., \& Šliogerienè, J. (2017). Moodle as virtual learning environment in developing language skills, fostering metacognitive awareness and promoting learner autonomy. Pedagogika, 127(3), 176-185. https://doi.org/10.15823/p.2017.47

Gurbin, T. (2015). Metacognition and technology adoption: Exploring i. Procedia Social and Behavioral Sciences, 191, 1576-1582. https://doi.org/10.1016/j.sbspro.2015.04.608

Halamish, V. (2018). Pre-service and in-service teachers' metacognitive knowledge of learning strategies. Frontiers in Psychology, 9(NOV), 1-5. https://doi.org/10.3389/fpsyg.2018.02152 
Horn, M. B. (2020, March). COVID-19's long-term impacts on education in 2020 and beyond. EdSurge.

Hsieh, V. C.-R. (2020). Putting resiliency of a health system to the test: COVID-19 in Taiwan. Journal of the Formosan Medical Association, $0(0)$, 3-4. https://doi.org/https://doi.org/10.1016/j.jfma.2020.03.002

Hughes, A. J. (2017). Educational complexity and professional development: Teachers' need for metacognitive awareness. Journal of Technology Education, 29(1), 25-44. https://doi.org/10.21061/jte.v29i1.a.2

Ingole, M., \& Pandya, S. (2016). Interactive effect of meta-cognitive strategies-based instruction in mathematics and self-efficacy of students on their meta- cognitive awareness. Third Asia Pacific Conference on Advanced Research, 341-351.

Irawan, H. (2020). Inovasi pendidikan sebagai antisipasi penyebaran Covid-19 (Educational innovations anticipating the spread of [Covid-19]). In Ombudsman RI. Ombusman RI.

Jackson, J. K., Weiss, M. A., Schwarzenberg, A. B., \& Nelson, R. M. (2020). Global economic effects of COVID-19.

Jain, K. R., \& Kumar, R. (2013). Cognitive style and meta-cognitive awareness in adults. Prachi Journal of Psychocultural Dimension, 29(1), 1-14.

Jaleel, S., \& Premachandran, P. (2016). A study on the metacognitive awareness of secondary school students. Universal Journal of Educational Research, 4(1), 165-172. https://doi.org/10.13189/ujer.2016.040121

Joo, B. K. (Brian), Zigarmi, D., Nimon, K., \& Shuck, B. (2017). Work cognition and psychological well-being: The role of cognitive engagement as a partial mediator. Journal of Applied Behavioral Science, 53(4), 446-469. https://doi.org/10.1177/0021886316688780

Kallio, H., Virta, K., Kallio, M., Virta, A., Hjardemaal, F. R., \& Sandven, J. (2017). The utility of the metacognitive awareness inventory for teachers among in-service teachers. Journal of Education and Learning, 6(4), 78. https://doi.org/10.5539/jel.v6n4p78

Karamustafaoğlu, O., Bardak, Ş., \& Doğan Erkoç, S. S. (2018). Investigation of pedagogical content knowledge of a science teacher based on the metacognitive awareness of her students. In Pegem Egitim ve Ogretim Dergisi (Vol. 8, Issue 1). https://doi.org/10.14527/pegegog.2018.006

Karataş, K. (2017). Predicting teacher candidates' self-directed learning in readiness levels for terms of metacognitive awareness levels. Hacettepe Egitim Dergisi, 32(2), 451-465. https://doi.org/10.16986/HUJE.2016017218

Karp, P., \& McGowan, M. (2020, March). "Clear as mud" schools ask for online learning help as coronavirus policy confusion persists Australia news. The Guardian.

Kartini, D., \& Kristiawan, M. (2019). Pengaruh tunjangan profesi dan motivasi kerja terhadap kinerja guru. Kelola: Jurnal Manajemen Pendidikan, 6(1), 25-33. https://doi.org/10.24246/j.jk.2019.v6.i1.p25-33 
Kemendikbud. (2020). Belajar dari rumah, satuan pendidikan dapat pilih platform pembelajaran jarak jauh sesuai kebutuhan (Learning from home, education units can choose distance learning platforms as needed). Kementerian Pendidikan dan Kebudayaan, Republik Indonesia.

Khan, M., Kazmi, S., Bashir, A., \& Siddique, N. (2020). COVID-19 infection: Origin, transmission, and characteristics of human coronaviruses. Journal of Advanced Research, 24, 91-98. https://doi.org/10.1016/j.jare.2020.03.005

Kim, J., Nimon, K., Song, J. H., \& Zigarmi, D. (2015). Toward employee work passion and performance: A validation of the work cognition inventory in korea. Human Resource Development International, 18(2), 169-190. https://doi.org/10.1080/13678868.2015.1026550

Kube, S., Maréchal, M. A., \& Puppe, C. (2012). The currency of reciprocity: Gift exchange in the workplace. American Economic Review, 102(4), 1644-1662. https://doi.org/10.1257/aer.102.4.1644

Kusumawardhani, P. N. (2017). Does teacher certification program lead to better quality teachers? Evidence from Indonesia. Education Economics, 25(6), 590-618. https://doi.org/10.1080/09645292.2017.1329405

Kuvac, M., \& Koc, I. (2018). The effect of problem-based learning on the metacognitive awareness of pre-service science teachers. Educational Studies, 00(00), 1-21. https://doi.org/10.1080/03055698.2018.1509783

Lailatussaadah, L. (2015). Upaya peningkatan kinerja guru. Intelektualita, 3(1), 15-25.

Lee, C. B., Teo, T., \& Chai, C. S. (2010). Profiling pre-service teachers' awareness and regulation of their own thinking: Evidence from an Asian country. Teacher Development, 14(3), 295-306. https://doi.org/10.1080/13664530.2010.504010

Lee, I. (2018). Future directions for writing teacher cognition. In The TESOL Encyclopedia of English Language Teaching (pp. 1-7). John Wiley \& Sons, Inc. https://doi.org/10.1002/9781118784235.eelt0563

Li, C., Yang, Y., \& Ren, L. (2020). Genetic evolution analysis of 2019 novel coronavirus and coronavirus from other species. Infection, Genetics and Evolution, 82(March), 1-3. https://doi.org/10.1016/j.meegid.2020.104285

Lin, Q., Zhao, S., Gao, D., Lou, Y., Yang, S., Musa, S. S., Wang, M. H., Cai, Y., Wang, W., Yang, L., \& He, D. (2020). A conceptual model for the coronavirus disease 2019 (COVID-19) outbreak in Wuhan, China with individual reaction and governmental action. International Journal of Infectious Diseases, 93, 211-216. https://doi.org/10.1016/j.ijid.2020.02.058

Mahase, E. (2020). Covid-19: WHO declares pandemic because of "alarming levels" of spread, severity, and inaction. BMJ (Clinical Research Ed.), 368(m1036), 1. https://doi.org/10.1136/bmj.m1036

Manasia, L., Ianos, M. G., \& Chicioreanu, T. D. (2020). Pre-service teacher preparedness for fostering education for sustainable development: An empirical analysis 
of central dimensions of teaching readiness. Sustainability (Switzerland), 12(1), 4-6. https://doi.org/10.3390/SU12010166

Marjon, M., \& Nugroho, K. U. Z. (2019). The competence of teachers based on academic qualification and gender. Journal of Physics: Conference Series, 1318(1), 19. https://doi.org/10.1088/1742-6596/1318/1/012136

Mart, Ç. T. (2013). A passionate teacher: Teacher commitment and dedication to student learning. International Journal of Academic Research in Progressive Education and Development, 2(1), 2226-6348.

Maryati, T., Khasanah, S. U., \& Maf'ula, V. Y. (2020). Contribution of teacher's teaching skills and students' intrapersonal intelligence toward metacognitive awareness of students in state vocational school in Blitar. Journal of Physics: Conference Series, 1470, 012045. https://doi.org/10.1088/1742-6596/1470/1/012045

Memnun, D. S., \& Akkaya, R. (2009). The levels of metacognitive awareness of primary teacher trainees. Procedia - Social and Behavioral Sciences, 1(1), 1919-1923. https://doi.org/10.1016/j.sbspro.2009.01.337

Mirķe, E., Cakula, S., \& Tzivian, L. (2019). Measuring teachers-as-learners' digital skills and readiness to study online for successful e-learning experience (Vol. 21, Issue 2, pp. 5-16). Sciendo. https://doi.org/10.2478/jtes-2019-0013

Muazza, M., Mukminin, A., Rahman, K. A., Wijayanti, A., \& Admi, N. (2019). The recruitment policy for non-civil servant (Non-PNS) teachers at public senior high school in Sarolangun regency. Advances in Social Science, Education and Humanities Research, May, 293-296. https://doi.org/10.2991/icream-18.2019.60

Mukhtar, M., Hidayat, H., \& Meichaty, A. (2019). Effectiveness of teacher certification in improving service professional service in Madrasah Aliyah State. International Journal of Research Granthaalayah, 7(12), 292-314. https://doi.org/10.5281/zenodo.3604565

Musthafa, M., Kuswandi, K., \& Cahyono, R. (2017). Effects teacher certification and teacher commitment on teacher performance. International Journal of Scientific Research and Management, 5(1), 5016-5025. https://doi.org/10.18535/ijsrm/v5i1.01

Nimon, K., \& Zigarmi, D. (2015). The Work Cognition Inventory: Initial Evidence of Construct Validity for the Revised Form. Journal of Career Assessment, 23(1), 117136. https://doi.org/10.1177/1069072714523241

Nimon, K., Zigarmi, D., Houson, D., Witt, D., \& Diehl, J. (2011). The work cognition inventory: Initial evidence of construct validity. Human Resource Development Quarterly, 22(1), 1-35. https://doi.org/10.1002/hrdq.20064

Okoza, J., \& Aluede, O. (2014). Fostering metacognitive awareness among teachers: Implications for the Nigerian school system. Africa Education Review, 11(4), 614-637. https://doi.org/10.1080/18146627.2014.935006

Ozturk, N. (2018). The relation between teachers' self-reported metacognitive awareness and teaching with metacognition. International Journal of Research in Teacher Eductaion, 9(2), 26-35. 
Palantis, N. J., Mohamed, Johan, A., Ibrahim, A. S. M., Ismail, S. H., Anuar, N. K., Ma'rof, A. M., \& Buang, N. (2018). Patterns of metacognitive awareness among primary school teachers. Jurnal VARIDIKA, 29(2), 141-146. https://doi.org/10.23917/varidika.v29i2.5629

Pantiwati, Y., \& Husamah, H. (2017). Self and peer assessments in active learning model to increase metacognitive awareness and cognitive abilities. International Journal of Instruction, 10(4), 185-202. https://doi.org/10.12973/iji.2017.10411a

Park, I. (2005). Teacher commitment and its effects on student achievement in American high schools. Educational Research and Evaluation, 11(5), 461-485. https://doi.org/10.1080/13803610500146269

Peeters, W. (2015). Metacognitive awareness in foreign language learning through Facebook. Dutch Journal of Applied Linguistics, 4(2), 174-192. https://doi.org/10.1075/dujal.4.2.03pee

Perry, J., Lundie, D., \& Golder, G. (2019). Metacognition in schools: what does the literature suggest about the effectiveness of teaching metacognition in schools? Educational Review, 71(4), 483-500. https://doi.org/10.1080/00131911.2018.1441127

Purnomo, J., \& Jailani, J. (2019). ICT literacy of high school mathematics teacher: Online learning competence with heutagogical approach. Journal of Physics: Conference Series, 1321(3), 1-5. https://doi.org/10.1088/1742-6596/1321/3/032128

Ramos, M. F. H., Ramos, E. M. L., Pontes, F. A. R., Casanova, D. C. G., Silva, S. S. da C., \& Azzi, R. G. (2018). Characterization of basic education teachers based on the social cognitive model of job satisfaction. Paidéia (Ribeirão Preto), 28(e2811), 1-8. https://doi.org/10.1590/1982-4327e2811

Rapchak, M. E. (2018). Collaborative learning in an information literacy course: The impact of online versus face-to-face instruction on social metacognitive awareness. Journal of Academic Librarianship, 44(3), 383-390. https://doi.org/10.1016/j.acalib.2018.03.003

Razak, N. A., Darmawan, I. G. N., \& Keeves, J. P. (2009). Teacher Commitment. In L. J. Saha \& A. G. Dworkin (Eds.), International Handbook of Research on Teachers and Teaching (pp. 343-360). Springer Science. https://doi.org/10.1007/978-0-387-733173_22

Rokhman, F., Ahmadi, F., \& Kusumaningtyas, R. D. (2017). The strategic role of teacher training institute (LPTK) in building professional teacher. Advances in Social Science, Education and Humanities Research, 118, 23-32. https://doi.org/10.2991/icset-17.2017.5

San-Martín, S., Jiménez, N., Rodríguez-Torrico, P., \& Piñeiro-Ibarra, I. (2020). The determinants of teachers' continuance commitment to e-learning in higher education. Education and Information Technologies, 25, 1-21. https://doi.org/10.1007/s10639020-10117-3

Schmidt, K., Lachner, A., Stucke, B., Rey, S., Frömmel, C., \& Nückles, M. (2012). How metacognitive awareness caused a domino effect in learning. In J. van Aalst, B. J. 
Reiser, C. Hmelo-Silver, \& K. Thompson (Eds.), 10th International Conference of the Learning Sciences: The Future of Learning, ICLS 2012 - Proceedings (Vol. 1, pp. 4855). International Society of Learning Sciences.

Schraw, G. (1998). Promoting general metacognitive awareness. 113-125.

Schraw, G., \& Dennison, R. S. (1994). Assessing metacognitive awareness. Contemporary Education Psychology, 19(4), 460-475. https://doi.org/10.1006/ceps.1994.1033

Shernoff, E. S., Maríñez-Lora, A. M., Frazier, S. L., Jakobsons, L. J., Atkins, M. S., \& Bonner, D. (2011). Teachers supporting teachers in urban schools: What iterative research designs can teach us. School Psychology Review, 40(4), 465-485.

Su, L., Ma, X., Yu, H., Zhang, Z., Bian, P., Han, Y., Sun, J., Liu, Y., Yang, C., Geng, J., Zhang, Z., \& Gai, Z. (2020). The different clinical characteristics of corona virus disease cases between children and their families in China - the character of children with COVID-19. Emerging Microbes \& Infections, 9(1), 707-713. https://doi.org/10.1080/22221751.2020.1744483

Tambingon, H. N. (2018). The influence of principal leadership style and teacher work motivation on the performance of certified teachers at SMA Negeri Kotamobagu, North Sulawesi, Indonesia. Journal of Education and Learning (EduLearn), 12(3), 357-365. https://doi.org/10.11591/edulearn.v12i3.8248

Tanas, L., Winkowska-Nowak, K., \& Pobiega, K. (2020). The importance of teachers' need for cognition in their Use of technology in mathematics instruction. Frontiers in Psychology, 11, 1-11. https://doi.org/10.3389/fpsyg.2020.00259

Tao, K.-C., Hsieh, T.-F., Hsu, C.-Y., Yang, J.-J., \& Sia, W. Y. (2019). A study on the intention of using online e-learning platform to assist in teaching of junior high school teachers (pp. 41-44). Association for Computing Machinery. https://doi.org/10.1145/3345120.3345194

Thien, L. M., Abd Razak, N., \& Ramayah, T. (2014). Validating teacher commitment scale using a Malaysian sample. SAGE Open, 4(2), 1-9. https://doi.org/10.1177/2158244014536744

Turky, M. (2018). Enhancing metacognition skills by using reflective e-portfolio. SSRN Electronic Journal. https://doi.org/10.2139/ssrn.3058030

UNESCO. (2020a). Distance learning solutions. UNESCO's COVID-19 Education Response.

UNESCO. (2020b). School closures caused by Coronavirus (Covid-19). COVID-19 Educational Disruption and Response.

Uriegas, B., Kupczynski, L., \& Mundy, M. A. (2014). A comparison of traditional and alternative certification routes on classroom management. SAGE Open, 4(4), 1-6. https://doi.org/10.1177/2158244014553599

van Fleet, J. (2020). Education in the time of COVID-19. Global Partnership for Education. 
Wahyudi, N. (2020). Imbas pandemi virus corona bagi dunia pendidikan Indonesia dan global (The impact of the corona virus pandemic for the world of education in Indonesia and globally). Kumparan.

Wall, K., \& Hall, E. (2016). Teachers as metacognitive role models. European Journal of Teacher Education, 39(4), 403-418. https://doi.org/10.1080/02619768.2016.1212834

Watkins, J. (2020). Preventing a covid-19 pandemic. The BMJ, 368(February), 1-2. https://doi.org/10.1136/bmj.m810

Welch, P., Young, L., Johnson, P., \& Lindsay, D. (2018). Metacognitive awareness and the link with undergraduate examination performance and clinical reasoning. MedEdPublish, 7(2), 1-18. https://doi.org/10.15694/mep.2018.0000100.1

Wen, Y.-H. (2012). A study on metacognition of college teachers. The Journal of Human Resource and Adult Learning, 8(1), 80-91.

Wenham, C., Smith, J., \& Morgan, R. (2020). COVID-19: the gendered impacts of the outbreak. The Lancet, 395(10227), 846-848. https://doi.org/10.1016/S01406736(20)30526-2

Wilson, N. S., \& Bai, H. (2010). The relationships and impact of teachers' metacognitive knowledge and pedagogical understandings of metacognition. Metacognition and Learning, 5(3), 269-288. https://doi.org/10.1007/s11409-010-90624

Zacharo, K., Marios, K., \& Dimitra, P. (2018). Connection of teachers' organizational commitment and transformational leadership. A case study from Greece. International Journal of Learning, Teaching and Educational Research, 17(8), 89-106. https://doi.org/10.26803/ijlter.17.8.6

Zeichner, K. M. (2008). A critical analysis of reflection as a goal for teacher education. Educação \& Sociedade, 29, 535-554. https://doi.org/10.1590/S010173302008000200012

Zhang, W., Wang, Y., Yang, L., \& Wang, C. (2020). Suspending classes without stopping learning: China's education emergency management policy in the COVID-19 outbreak. Journal of Risk and Financial Management, 13(3), 55. https://doi.org/10.3390/jrfm13030055

Zhang, Y., Chen, B. L., Ge, J., Hung, C. Y., \& Mei, L. (2019). When is the best time to use rubrics in flipped learning? A study on students' learning achievement, metacognitive awareness, and cognitive load. Interactive Learning Environments, 27(8), 1207-1221. https://doi.org/10.1080/10494820.2018.1553187

Zohar, A. (1999). Teachers' metacognitive knowledge and the instruction of higher order thinking. Teaching and Teacher Education, 15(4), 413-429. https://doi.org/10.1016/S0742-051X(98)00063-8 